\title{
As If Republican Interpretation
}

\author{
Jerry Mashaw $\dagger$
}

I agree with Cass Sunstein that the time has come to develop the implications of republicanism, or "neo-republicanism," for American public law. After all, if being a republican means having a commitment to some version of democratic self-governance, combined with an aspiration for collective decisionmaking that goes beyond the mere aggregation of individual preference into some vector of "public" decisions, most of us can easily view ourselves as republicans. The crucial question has to do with the concrete meaning of republicanism for American public law and public institutions.

The task for republicans involves at least two sorts of theorizing. First, we must sort out our normative commitments and give them determinate shape. Otherwise republicanism as a normative theory will give us no purchase on the problems that we confront. Second, we must have a positive theory of legal and institutional dynamics. We must be able to specify how legal and political institutions-from electoral voting to legislative processes to judicial decisionmaking - work or can be made to work. Otherwise we cannot choose rules or construct institutions that will pursue our normative ends.

In this regard we should be alert to the experience of other movements which favored "rational democracy." Our "progressive" forebearers surely were as aware of the corruptions of legislative politics as are contemporary neo-republicans, and surely they were as determined to attack the evils of their day through institutional reform. And yet they were required to confess within a few short years of the foundation of their movement that they had seriously misunderstood the dynamics of public opinion and, therefore, the probable effects of the principal reform strategies-direct democracy in the form of the initiative, referendum, and recall-that they had inherited from the populists. They were thus required to shift to a completely new theory of how rational democracy could be constructed. ${ }^{1}$ That theory ultimately exalted a bureaucratic process that many contemporary critics, including neo-republicans, ${ }^{2}$ see as a major stumbling block

$\dagger$ William Nelson Cromwell Professor of Law, Yale Law School.

1. The disillusionment with public opinion is well illustrated by W. Lippman, The Phantom Public (1925). The earlier enthusiasm for public opinion is captured in J. Bryce, The AMERICAN Commonwealth (3d ed. 1904), the first American edition of which appeared in 1889.

2. See, for example, Michelman, Supreme Court 1985 Term-Forward: Traces of Self- 
to the achievement of the sort of inclusionary, democratic politics that the earlier progressive movement had been so eager to affirm.

For me, therefore, the most revealing portion of Professor Sunstein's Article is Section III, "Implications," which asserts, however tentatively, some of the consequences that Sunstein perceives as flowing from the normative vision of the earlier, and much more extended, part of his Article. Indeed, I believe that to advance Sunstein's project as he defines it, one must concentrate on applications and implications. It is here, in the context of concrete rules, practices, and institutions, that both the meaning and the acceptability of Sunstein's theory can best be evaluated.

I propose, therefore, to focus on one set of implications-what republicanism means or should mean for the interpretation of statutes. Indeed, I restrict my analysis to only one or two of Sunstein's examples within that set of issues. Despite this narrow focus, I arrive at some rather general conclusions. First, I believe that Sunstein's abstract vision of the interpretive enterprise is one that most lawyers, indeed most Americans, would (wrongly) reject. Nevertheless, second, I think that the Sunstein model of interpretation would, in practice, operate well within the bounds of what most of us view as appropriate judicial conduct. Unfortunately, third, this is not good news for Sunstein's theory. Acceptability in practice reveals not a happy synthesis of thesis and antithesis, but the relative emptiness of Sunstein's normative and positive vision as it is here articulated.

In the end, I conclude that Sunstein's theory operates to guide interpretation only at the rather vague level of symbolic appropriateness. While to my knowledge no interpretive theory really does more, this is a serious problem for the general neo-republican enterprise. For, if the republican revival is in substantial part an attempt to confront critics from both the Right and Left who view the exercise of collective authority in American politics and law as no more than the seizure of state power by private interests, then a thin version of republican theory will not answer their challenge. Indeed, it may produce extensions of the very deformations of political life that both critics and republicans alike abhor.

\section{I.}

Any theory of statutory interpretation is at base a theory about constitutional law. It must at the very least assume a set of legitimate institutional roles and legitimate institutional procedures that inform interpretation. Otherwise, rudimentary questions, such as whether a particular document presented for interpretation is a statute, or whether the presentation of that document in a particular context calls for an authoritative interpretation of it, cannot be answered. Beyond these very basic questions

Government, 100 HARv. L. REV. 4 (1986), who begins his lament with an archtypical story of administrative overgeneralization. 
lie many more that determine ultimately what it means to speak authoritatively in a legislative or in a legal-interpretive voice. Such questions can be answered only by reference to the fundamental normative and institutional attributes of the state.

With respect to most issues of statutory interpretation, of course, these sorts of questions pass by unasked and unanswered. The interpretive problems presented are simply not of sufficient moment to call forth an inquiry into our most basic assumptions or theories about the constitutional order. But the questions lie there, not far beneath the surface, waiting to be uncovered and examined whenever the interpretive going gets tough.

As I read his Article, Cass Sunstein invites us to imagine with him that some, perhaps all, of the interpretive aids that we call upon in routine interpretive situations are, or should be, attempts to capture some feature of our constitutional order. Thus, the standard routines for giving or discerning meaning, including the rules of thumb that we call the "canons of statutory interpretation," are to be understood as second-order constitutional rules. Like the rules of a well-constructed rule utilitarian moral system, their virtue lies in their simplicity and decisiveness-characteristics which limit both the decisional effort and the decisional errors that we might fall into if we attempted to consult the fundamental features of the constitutional order directly in resolving every legal-interpretive dispute.

As Sunstein recognizes, there is a practical problem with this vision of canonical interpretation. The canons of construction often march in matched pairs that point in opposite directions. ${ }^{3}$ Because there is no canon for the use of the canons-for choosing between two contradictory canons, or a canon and its exceptions-the interpreter must consult some ground for decision that is either separate from or lies behind the canons themselves. Rather than having a set of second-order rules that eliminate the need for laborious and problematic theoretical inquiry into the nature of the constitutional order, we seem to have a set that demands just such an inquiry. For only an exploration of fundamental constitutive presuppositions can hope to resolve the contradictory interpretive advice that the canons themselves provide.

Yet, the traditional indecisiveness of the canons need not be a roadblock to the building of interpretive theories. Indeed, it motivates the search for theory. And, the exploration of first principles that the canons seem to demand of us might lead to any number of outcomes. We might conclude that the canons, or some of them, are not really crystallized rules of thumb reflecting some sense of constitutional appropriateness, but instead are

3. See Llewellyn, Remarks on the Theory of Appellate Decision and the Rules or Canons About how Statutes are to be Construed, 3 VAND. L. REv. 395 (1950). 
vestiges of other nonconstitutional considerations. We might discover some constitutional theory that explodes the contradictions that we think we see in the canons and that provides a convincing unification of the interpretive maxims that history has handed down to us. We might, on the other hand, discover that the canons and their contradictions are just an all-tooaccurate reflection of the underlying theoretical disarray that is the truly basic characteristic of our legal order. Or, again, we might find that we have a satisfactory constitutional theory, but one that cannot happily make room for all the approaches that are embodied in the canons of statutory construction. On this latter view we would then have a normative basis for choosing amongst the canons-favoring those that seem to implement the basic principles of our constitutional order and rejecting those that do not.

As I read his Article, it is this last position that Sunstein wants to take up. For him, a "modern" or "neo" republican normative theory best explains our constitutional arrangements and aspirations. It is from the standpoint of this theory that we can both understand the underlying purposes of some of our canons of construction and discern which of them may be valuable and which may be misleading guides to the interpretation of statutes. The approach suggested thus has both positive/explanatory and normative/decisional elements. We should try to understand individual canons as if they supported republican principles. If they cannot be understood in this way, they either must be rejected or defended on some other ground.

Stated in this way, the Sunstein argument has much to commend it. It recognizes both the need to ground interpretive approaches in the norms and structures of the Constitution and the need to pursue interpretation in terms of some decisional directives that are more precise and meaningful than a vague injunction to "interpret in the light of our constitutional presuppositions." Sunstein's choice of normative foundations is also attractive. He sets out an abstract version of liberal, democratic republicanism that resonates both with much of modern constitutional practice and with modern understandings of the constitutional aspirations of 1787. For Sunstein, statutory interpretation is the pursuit of the public interest.

At this level, Sunstein's argument has the added attraction of providing an alternative to the rather depressing interpretive paradigms recently proposed by scholars heavily influenced by the public choice literature of the past four decades. ${ }^{4}$ For these scholars the image of the legislature is the image of private contract. Legislation is but a set of "deals" between interest groups and re-election-oriented politicians. As such, it aggregates without synthesizing, it compels without expressing. Interpretation, on this view, is only the discernment of the precise degree to which state

4. E.g., Easterbrook, Statutes' Domains, 50 U. CHI. L. REv. 533 (1983); Posner, Statutory Interpretation-In the Classroom and in the Courtroom, 50 U. CHI. L. REv. 800 (1983). 
power has been aligned to private interests. And in this vision of legislation, the public choice scholars of the Right tend to join forces with the "crits" of the Left. ${ }^{5}$ Sunstein here seems to have embarked on the project of preserving an idealistic and reformist center. ${ }^{8}$

Hence, I, for one, want to believe the Sunstein story-to be convinced that his is the true, at least the best, vision of how statutes should be interpreted. But there is much work left to be done. In this brief Comment, of course, we cannot really begin to dissect all the problematics of what I am calling the "as if republican" approach to statutory interpretation. Let me therefore concentrate on two sets of issues that seem to me to be central to a convincing and workable theory. The first set addresses the basic stance of the interpreter. What is the function of the interpreter? What is it that he, she, or it thinks it is doing? Can we give a convincing account of why that function or interpretive role is appropriate in our constitutional system?

The second is the capacity of the normative framework to do some interpretive work. A strong form of interpretive work, for example, would be a capacity to decide hard cases. A weaker version of interpretive efficacy might be the normative framework's capacity to confine interpretive results within some subset of possible outcomes, all of which are constitutionally appropriate. Weaker yet would be a capacity merely to focus interpretive issues in distinctive and symbolically appropriate ways. As the form of interpretive work weakens, of course, so does the power and attractiveness of the theory.

Indeed, as we shall see, a theory that does little interpretive work may be inadequate both to inform and to sustain the interpretive role that the theory simultaneously affirms. This is, I fear, the problem with Sunstein's scheme and is why a focus on interpretive implications has much to tell us about his basic theory of republicanism itself. The two sets of issues thus are connected, but for now let me take them up in turn.

5. See, e.g., Hutchinson \& Morgan, The Semiology of Statutes, 21 HARv. J. ON LEgIS. 583 (1984); Parker, The Past of Constitutional Theory-And Its Future, 42 Oн1о ST. L.J. 223 (1981). The latter participate in a long tradition which includes such classics as C. BEARD, AN ECONOMIC INTERPRETATION OF THE Constitution (1913) and E.E. SchatTschneider, The SEMISovereign PEOPLE (1960). There is, of course, no necessary connection between either the analytic methodology of public choice or the deconstructionist methodology of much of critical legal theory and particular political commitments. See, e.g., Ackerman, Beyond Carolene Products, 98 HARV. L. Rev. 713 (1985) (harnessing public choice ideas to an interventionist political agenda). Nevertheless, there is a conventional contemporary association of these methodological and political postures to which the text subscribes.

6. He is not the first in recent years to stake out this territory in relation to statutory interpretation. See, e.g., Farber \& Frickey, The Jurisprudence of Public Choice, 65 TEx. L. REv. 873 (1987); Maccy, Promoting Public-Regarding Legislation Through Statutory Interpretation: An Interest Group Model, 86 Colum. L. Rev. 223 (1986). 
II.

The idea of the function of the interpreter is not at all easy to unpack. Interpreters come in many shapes and sizes-individuals, private collectivities, and coordinate and subordinate officials, to name but the major categories. Is a theory of interpretation to give the same or a different answer to the question of the interpretive function for all of these different interpreters? But perhaps we can put this particular puzzle aside for the moment, for Sunstein's analysis seems to imagine that the interpreter is a court, perhaps the Court. What then is the judicial role as statutory interpreter, or, more precisely, what is the judicial role as a statutory interpreter in a republican polity?

The general features of Sunstein's answer are not difficult to discern. Republican courts are "to use interpretation to guard against or limit ... possible malfunctions in the legislative process." This is the role that Sunstein sees for some existing canons and, certainly, for some new ones that he suggests. Indeed, the task of developing new canons may be a large one because "it would be surprising if existing canons of construction were sufficient." form of republican monitoring. Judicial interpretation and judicial review are largely congruent if not identical. In both, courts police legislative activity to avoid anti-republican results.

In terms of practical effect, of course, monitoring legislative outcomes via judicial review and judicial interpretation are generally thought to be different. According to the conventional wisdom, interpretation is a weaker, less intrusive form of judicial action. Yet, the opposite position is equally plausible. Interpretive monitoring can be both more powerful and more creative than judicial review. After all, a reviewing court finding a legislative malfunction merely nullifies the law. The republican interpreter goes one step further, substituting an appropriately republican norm for the "defective" one placed before it by the legislature. Here "as if republican interpretation" begins to take on a vaguely sinister meaning. The interpreter, construing the statute as if it had been enacted by a republican legislature pursuing the public good, may transform the actual legislature into one almost purely hypothetical.

To be sure, this need not always be the case in Sunstein's system. Some of his republican guides to interpretation merely constrain the reach of statutes. For example, some rules counsel narrow construction of appropriations bills, procedural requirements, and potentially pre-emptive federal legislation, or of statutes arguably conferring broad discretion on administrators to decide questions of high political moment. Here republican interpretive monitoring acts only as a partial veto or invalidation, like a

7. Sunstein, Beyond the Republican Revival, 97 YaLE L.J. 1539, 1582 (1988).

8. Id at 1583 . 
limited form of judicial review. Other suggestions are more activist; interpretive monitoring for "proportionality" or "coherence" would seem to have the effect of rewriting statutory provisions to "republicanize" them.

When Sunstein speaks of his "principle of proportionality," for example, he cites as a case implicitly accepting his approach the famous OSHA benzene decision, Industrial Union Department, AFL-CIO v. American Petroleum Institute. ${ }^{10}$ One common understanding of the Supreme Court's judgment in that case, the view Sunstein seems both to hold and to applaud, is that the Court rewrote the Occupational Safety and Health Act in order to avoid affirming what it perceived to be an unreasonably costly health regulation. Sunstein's approach thus seems to imply a strong form of judicial lawgiving.

There was certainly no reason, for example, for Congress to have anticipated that the Supreme Court would add a "significant risk" requirement to the Occupational Safety and Health Act, even if it were well understood that the proportionality principle was to function as a background guide to statutory interpretation. After all, the litigants in that case were busy attempting to structure the issue of proportionality around the quite separate question of whether the definitions section of the Act implied a demand for a cost-benefit calculation." Hence the "benzene case" itself demonstrates that the opportunities for creative interpretation of the terms of statutes to move them in the direction of the proportionality principle are quite substantial. Moreover, if we are to understand the proportionality principle as constitutionally based, then presumably a statute attempting to instruct the courts to ignore questions of proportionality (as the Occupational Safety and Health Act arguably did) ${ }^{\mathbf{1 2}}$ or any other republican principle would raise serious constitutional questions. Such a statute itself should therefore be subjected to an interpretation that would induce a republican spin, perhaps, for example, by limiting the instruction to those circumstances in which the legislative intent to violate republican principles is "clear." It will be difficult under this theory for the actual legislature to avoid becoming a hypothetical one.

Given the common assumption in our legal system that the role of the judiciary in statutory interpretation is something like "behaving as a faithful agent of the legislature," Sunstein's suggestions may be viewed by many with considerable alarm. But I do not want to be counted in that number. For I believe that there are good reasons for taking the sort of approach to the judicial role that Sunstein's republican interpretive

9. Id.

10. 448 U.S. 607 (1980).

11. This was the theory on which the case was decided below, and one which had somewhat greater textual support in the statute itself. Industrial Union Dep't AFL-CIO v. American Petroleum Inst., 581 F.2d 493 (5th Gir. 1978).

12. The Supreme Court later held that no cost-benefit requirement should be read into the Act. See American Textile Mfg. Inst. v. Donovan, 452 U.S. 490 (1981). 
scheme seems to imply. Indeed, I believe that the common faithful agency idea can never be much more than a starting point for interpretation. It ceases to be informative as soon as it is needed-whenever there is some reason for the agent to wonder what the principal meant. And the occasions for such wonderment are ubiquitous.

Consider how rapidly context begins to overwhelm text as the faithful agent begins to interpret. It is not possible to imagine an interpretive role of the conventional "faithful-agency" sort without also imagining that the agent must interpret its instructions against the background of a set of understandings concerning its principal. Even if one believes that these background understandings lie firmly in the background, waiting to be called forth only to resolve interpretive conundra (usually spoken of as "gaps"), the idea of a conundrum, gap, ambiguity, or whatever is not selfdefining. What the text says and where it is silent, vague, contradictory, incoherent or ambiguous thus also is a function of the application of the background norms or principles-the contextual understandings within which any interpretive enterprise goes forward. These contextual understandings must bring into play the way in which the constitutional order defines or conceives of the legislative function.

This leads to the realization that the faithful agent is one who is faithful to the principal as a legitimate lawgiver within the constitutional polity-to the legislature as constitutionally conceived or imagined. The judge as interpreter must consider how the constitutional order conceives of both the judicial and the legislative roles, as well as how those institutions are meant to interact. The judge as monitor or creative lawgiver, thus, is not sharply distinguishable from the judge as faithful agent of the legislature. In case of doubt, the judge should imagine a legislature (principal) going about its rightful business in a constitutionally appropriate manner.

Indeed, if one believed that the legislature were structured to act and intended to behave as a good republican legislature, then "as if republican" interpretation would be grounded precisely in a combination of those empirical beliefs and a normative belief that the court should behave as a faithful agent of the legislature. The judicial interpreter as a corrector of republican legislative malfunctions would be nothing more, on this view, than an agent who is alert to the ever-present possibility that a too literal or too nonreflective following of the principal's instructions might seriously disserve the principal's underlying purposes or values.

Moreover, and I take this to be Sunstein's point, one can give a normative justification for "as if republican" interpretation. If it is the case that our constitutional system aspires to republican principles and that the structure of government is devised to support and defend those principles, then it should also be the case that the separation of powers (including not just judicial review but also judicial interpretation and application of the 
law) is a part of that scheme of republican aspiration and defense. Even for a court acting as a "faithful agent of the legislature," the Constitution commands that a vision be taken of the legislature, a vision that grants the legislature its proper place in the constitutional scheme. In a republican polity that place is the place of a republican assembly.

In this way, Sunstein's approach is quite reminiscent of other recent attempts at the development of theories of statutory interpretation. The distinctive feature of Sunstein's approach is that it goes beyond Calabresi's "fit"13 or Dworkin's "integrity"14 or Macey's notion of "ordinary interpretation"16 to specify a normative scheme that allows us to see the legal system whole. As in the Calabresi, Dworkin, or Macey systems, the interpreter's role is to fit particular bits of legal materials, including statutes, into the fabric of the legal order. Sunstein's fabric just has a particular texture and hue-republicanism.

One may, of course, reject all wholistic visions of the legal system. One might also take the view that even if the Constitution presumes that the legal fabric comprises a whole rather than bits and pieces or rags and stitches, that it is not the republican whole that Sunstein describes. But these are not issues that we can or need explore in this comment. Suffice it for now to say that there is an implicit and a quite convincing justification for Sunstein's "republican monitoring" view of the judicial role in statutory interpretation. "Monitoring" seems to be implied by any vision of the legal system that sees it as a whole and that sees interpretation as the inevitable device through which that "wholeness" is maintained. And, given the usual association of republican ideas with concepts like "disinterestedness" and "the public interest," canism as supplying the appropriate normative commitments for the interpreter goes some way toward answering a question that other theorists leave largely open: Why is coherence, whether styled as "fit," "integrity," or "ordinary interpretation," the crucial criterion of interpretive adequacy? In a republican legal system, a system focused on "the common good," the answer is obvious. A normatively fragmented legal system is simply inconsistent with the maintenance of the republican ideal of deliberative consensus. It is anti-republican, or at least non-republican.

And yet, having come this far with Sunstein, I fear that his project founders. Sunstein's particular brand of republicanism seems to me too vague a principle to do the work that is required for the unification of a presumptively wholistic legal order. Moreover, even where the value ma-

13. G. Calabresi, a Common law for the age of Statutes (1982).

14. R. DWORKIN, LAw's EMPIRE (1986).

15. Macey, supra note 6 .

16. See generally Wood, Interests and Disinterestedness in the Making of the Constitution, in Beyond Confederation: Origins of the Constitution and American National Identity 69 (R. Beeman, S. Botein \& E. Carter eds. 1987). 
trix is reasonably determinate, it is far from clear what set of second order rules of interpretive practice, "canons" in Sunstein's terminology, would effectively implement those norms. And if these things are true, then the path that we have just traversed to the justification of Sunstein's judge as monitor has also been cut off. If republicanism is vague in the abstract and ambiguous in application, then it cannot justify or necessitate the role of the monitor. It is precisely this problem with Sunstein's republicanism that is highlighted by an inquiry into the second criterion for an adequate theory of interpretation that we articulated earlier: the capacity of the normative framework to do interpretive work.

\section{III.}

Once again, we cannot here pursue many of the issues that Sunstein's article raises. We must be selective, and any selective discussion obviously risks distortion. I have chosen simply to discuss the first example that Sunstein uses to illustrate the interpretive implications of his theory. For I believe that this example is one that many will find intuitively plausible, and, yet, I believe it provides revealing glimpses of the twin difficulties at the core of Sunstein's enterprise. The first concerns the possibility of giving operational content to the critical republican virtue of deliberativeness; the second involves the interaction of the deliberative ideal with the other values that Sunstein affirms as a part of the modern republican's commitments.

Consider, therefore, the straightforward support Sunstein finds in republican ideals for the "canon" urging narrow construction of appropriations statutes. In Sunstein's view, this canon is justified by the notion that appropriations bills are often anti-republican because the appropriations process is "likely to be dominated by well-organized private groups"17 and also "lacks visibility." 18 My troubles with this notion are both positive and normative. As a factual matter, I am doubtful that the malfunctions that Sunstein perceives are sufficiently systematic to justify the canon. More importantly, consideration of what those malfunctions or their correction might entail obscures the underlying republican values that are being supported.

First, the positive difficulties. Surely Sunstein is right to be suspicious of substantive provisions in appropriations measures. They do seem "fishy" in some way. But is it in the way Sunstein suggests? I am not at all sure. For when I think of the two or three examples that spring most readily to my mind, they do not seem to illustrate the dangers that Sunstein's interpretive monitors should be concerned about.

For many years, for example, the agenda of American administrative

17. Sunstein, supra note 7 , at 1582.

18. Id. 
law reform was shaped by a desire to make virtually all administrative action subject to routine forms of judicial review. ${ }^{19}$ This reform agenda has now largely been accomplished. One milestone in that effort, drilled into the heads of generations of law students, was the statute providing for judicial review of the grandfather of federal regulatory authorities, the Interstate Commerce Commission. And the title of this landmark statute was the Urgent-Deficiencies Act of $1913^{20}$ - an appropriations statute.

To be sure there is some tendency today to view judicial review of administrative action as one of the tactics of disablement, if not capture, employed by well-organized private interests in their continuing politicolegal warfare with the administrative state. But that is hardly the view that supported the Urgent-Deficiencies Act reforms. Those provisions were premised on a general interest in making the rule of law a practical reality in the emerging positive or welfare state. The review provisions in question were attached to an appropriations bill for reasons of convenience. But this hardly signalled a triumph of private over general or public interests. The provisions adopted reflected discussions concerning the appropriate roles of regulatory commissions, specialized courts, and generalist courts that had been of continuous interest both inside and outside the Congress for a number of years.

Consider some more recent examples. In the 1980's much legislative business is done in one or another Omnibus Budget Reconciliation Act (OBRA). These are, indeed, grotesquely complex statutes that literally might include anything in the interest of reaching an acceptable overall budget compromise. The dangers of "dealmaking" seem all too real in these gigantic bills that few could bring themselves to read, much less understand. Yet I wonder whether it makes sense to view such legislation as inherently suspect. Even some of my least favorite OBRA legislation, such as that in 1981 constraining the growth of the Aid to Families with Dependent Children (AFDC) budget by making a series of substantive entitlements changes, ${ }^{21}$ hardly seems to fit Sunstein's vision of the hidden special interest deal.

Indeed, the budget reconciliation process could be viewed in some sense as an antidote to structural problems in the non-appropriations legislative process that promote private interest control. After all, the reigning vision of the Congress seems to be one of subcommittee governance in which powerful chairs use their positions to protect electorally significant clienteles. ${ }^{22}$ If that vision is correct, the post-1974 appropriations process might

19. See, e.g., L. Jaffe, Judicial Control of Administrative Action (1965).

20. 28 U.S.C. $\$ \S 1336,1398$ (1982).

21. Pub. L. No. $97-35$, ch. 1, 95 Stat. 843, 843-60 (1981).

22. See, e.g., M. Fiorina, Congress: Keystone of the Washington Establishment (1977); M. Hayes, Lobbyists and Legislators: A Theory of the Polttrcal Process (1981); D. Mayhew, Congress: The Electoral Connection (1974); W. Niskanen, Bureaucracy and Representattue Government (1971); K. Schlozman \& J. Tierney, Organized InTER- 
provide one of the few occasions for the Congress to break out of this balkanized, special-interest-dominated mold to consider an overall accommodation of conflicting interests subject to a global, and apparently public-interested, budget constraint.

Even specific limitations on the regulatory jurisdiction of federal agencies in appropriations riders might be given a similarly cheerful interpretation. I think, for example, of the directions to the National Highway Traffic Safety Administration (NHTSA) in the late 1970's and early 1980's that none of its appropriations be used to enforce a rule requiring that passenger cars be equipped with passive restraints. ${ }^{23}$ These riders reflected, not subterranean special interest pleading, but the frustrations of a significant number of representatives who found that limitations on NHTSA's regulatory authority were essentially not discussable within the committees and subcommittees having subject-matter jurisdiction over the agency. The riders thus represented an opening up of an otherwise virtually closed process to broader currents of sentiment and debate. Indeed, because the rule in question was not yet effective, those riders were making only a procedural and symbolic point.

To be sure, one can find appropriations measures that are within the core of the concerns about private interest capture that Sunstein expresses. I have no way of knowing either what the dominant pattern is in appropriations legislation or whether that pattern diverges systematically from legislation generally. But my counter-examples provide some reason to wonder whether Sunstein's canon will do more harm than good when viewed in a republican perspective. Indeed, they lead me to question whether a firm basis for subconstitutional interpretative rules can be derived from Sunstein's restrained, balanced, and prudential approach to republicanism. For that approach has at least the vices of its virtues. Its flexibility and contextuality seem to produce radical indeterminacy. Even if we clearly understand the norms that our interpretive theory seeks to implement, we seem to lack a crisp positive theory of legislative institutions that would guide implementation. ${ }^{24}$

Indeterminacy, unhappily, also seems to beset Sunstein's most fundamental normative commitments. Consider first the idea of deliberativeness that Sunstein employs. This notion is surely familiar. At base it demands only that political argument (and presumably political action) be some-

ests AND AMERICAN Democracy (1986).

23. These "nonenforcement" riders were attached to NHTSA's appropriations legislation from 1978 to 1980.34 Cong. Q. Almanac 61; 35 Cong. Q. Almanac 358-59.

24. The recent literature challenging the "public choice" or "interest group pluralist" vision of the legislature includes: R. Bower, I. POOL \& L. Dexter, AMERICAN Business and Public Policy (1963); R. Fenno, Congressmen in Committees (1973); J. Kingdon, Agenda, Alternatives and Public Policies (1984); A. MaAs, Congress and the Common Good (1980); Panning, Formal Models of Legislative Processes, in HandBook of Legislative Research 669-97 (G. Loewenberg, S. Patterson \& M. Jewell eds. 1985). 
thing more than the assertion of pre-political preferences. "Because I want to," is just not an argument in republican discourse. Nor is "Because they wanted it" a justification for legislative provision of some good, service, or institution. Action and argument must be oriented toward the public interest. So far so good; indeed, I agree. But does this principle have any interpretive bite? Does it help solve hard questions, narrow the interpretive field, or structure interpretive analysis in a distinctive and appropriate way?

I am doubtful. The one example that Sunstein cites of the application of the amendment-by-appropriations-is-disfavored canon, TVA v. Hill, ${ }^{25}$ seems either to have nothing to do with deliberativeness or to suggest, as our prior discussion indicated, that because deliberation about the public interest may pursue many goals and may come in many forms, use of the canon is as dangerous to deliberation as it is a support for it. The interpretive issue in TVA v. Hill was whether Congress meant in the Endangered Species Act to forbid the continuation of federal construction projects, begun before that Act's passage and funded continuously since, in the interest of preserving the habitat of a previously unknown species of fresh-water perch. In one sense this issue was not difficult. The Endangered Species Act contained no exceptions, and its literal terms covered the project and species in question. The problem was that stopping the project and forfeiting both its potential benefits and the previously expended planning and construction funds seemed silly. The "snail darter" had no known commercial, recreational, or other value. This pragmatic judgment sought legal refuge in the argument that Congress had impliedly amended the Endangered Species Act by continuing to appropriate funds for the Telico Dam after learning of the threat the dam posed to the snail darter's habitat.

The "canon" in question was obviously an answer of sorts to that argument. But one may certainly question whether that answer had anything to do with deliberativeness. Although we can readily identify those who will benefit in this instance from application or nonapplication of the canon, there is no suggestion that either the federal water project or the Endangered Species Act was "private interest" legislation. The conflict here is between two public interests. Moreover, if deliberativeness is to be judged by outcome-by the degree to which a statute as interpreted promotes general social welfare-the application of the canon in this case seems misplaced. Indeed, in arguing for his new canon of "proportionality," which apparently entails the proposition that all statutes be viewed as containing de minimis exceptions, ${ }^{26}$ Sunstein himself seems to be suggesting that the application of the appropriations disfavoring canon would

25. 437 U.S. 153 (1978).

26. Sunstein, supra note 7 , at 1583 . 
be wrong in a case like TVA v. Hill. At the very least, Sunstein's two canons, both presumably favoring republican deliberativeness, point in opposite directions.

On reflection, this result is not too surprising. Where the criterion of a satisfactory outcome is that $a$ vision of the public interest is being served, most statutory enactments pass muster. It is hardly surprising that republicanism, defined as public interested results, will have this characteristic. It will be an extremely rare case where interpretation involves choosing between a private interest and a public interest result. Nor does Sunstein provide any examples in which the consideration of the demands of deliberativeness suggest "uniquely correct outcomes," save for situations in which such considerations lead to an invalidation of the legislation as violating one or another existing constitutional protection of individual rights. ${ }^{27}$ And there the idea of republicanism provides no independent basis for invalidation.

Thus far, then, we have encountered the following problems in utilizing Sunstein's republican interpretive system. First, the one "canon" that we have analyzed in any detail might plausibly lead away from rather than toward republican results. Second, that republican canon seems to contradict another in the only example that Sunstein provides for its utilization. And third, if we leave aside problematic and conflicting republican canons to consult the value of republican deliberativeness directly, we seem to end up with an interpretive guideline having the nondecisiveness of the familiar post-New Deal rational basis test.

"As if republican" interpretation confronts something of a dilemma. For the system to do a strong form of interpretive work-to decide hard cases-it must have some rules such as the canons of construction. But republican canons are difficult to construct because republicanism itself is a substantive and procedural aspiration which must be pursued prudentially in any legislative context. Canonical exposition of rules produces immediate unease for an obvious reason: Hard-edged rules are procrustean and acontextual. Hence a complete set of republican canons should be expected to create choices among rules in every context-choices that presumably can be informed only by resort to the vague contours of republicanism itself. But to repair there is to abandon the hope that republican interpretation will solve interpretive problems. Almost always the interpretive problem is to choose between or among possible visions of the public interest, not to find a way to suppress "malfunctions." And, if this is true, then the interpretive stance that republicanism sought to justify collapses. Republican interpretive monitoring can hardly be necessary to unify a legal system within which virtually any result is acceptable.

For some this will be a virtue rather than a vice of Sunstein's vision. In

27. Sunstein, supra note 7, at 1584-89. 
a sense we have come full circle from our earlier conclusion that the faithful agency model of the interpreter merged imperceptibly into some form of normative monitoring model. We can now see that, at least where norms are as capacious as republicanism and factual contexts as indeterminate as our current positive theory of legislation, normative monitoring implies judicial activism of a degree and extent that is barely distinguishable from a naive attachment to the faithful agency model.

To be sure, our discussion up to this point concerns itself with only one of the values that inhabit Sunstein's neo-republican vision. But the justification of "bright line" interpretive rules and the decisiveness of republicanism itself is not aided by adding considerations beyond "deliberativeness" to the value matrix. Indeed, these problems are worsened appreciably once it is recognized that those values also require prudential and contextual application and that their suggestions about an appropriate interpretive posture may contradict the concrete implications of a consideration of deliberativeness.

Consider, for example, a republican interpreter faced with the not uncommon problem of determining the meaning to be given to statutory terms that seem to have been differently understood by certain members of the House and the Senate. Does Sunstein's republican vision of the interpretive enterprise tell us which house should have preference? Arguably it does: Both. From the standpoint of deliberativeness, the Senate understanding would seem to have the edge-at least if we understand deliberativeness to be facilitated by relative insulation from parochial political clamor. But what about political equality, one of the other virtues Sunstein ascribes to republicanism? On that basis the House view should get the nod.

Adding Sunstein's other values, universalism and citizenship, merely deepens the puzzle. Surely the smaller and more stably composed Senate has a better chance of achieving consensual outcomes and thus satisfying the aspiration for "universalism" as Sunstein presents it. And, just as surely, the House seems to represent the commitment to voter and small unit efficacy that is said to inhabit "citizenship."

There may be convergences amongst these values that point toward a set of uniquely republican canons of construction or that resolve particular interpretive difficulties. But even in the abstract these values seem to push in differing directions and to raise a host of issues concerning their meanings and possible interconnections. At the level of concrete application I am doubtful, to put it mildly, that a convergence of values will ever produce either determinate and nonconflicting canons or clear directions for the solution of interpretive conundra. The values that Sunstein espouses may in some sense describe a symbolically appropriate interpretive stance, but they are unlikely to decide hard questions or, indeed, to eliminate many plausible solutions. 
IV.

A less sympathetic critic than I am, therefore, might characterize Sunstein's interpretive approach as Hart and Sachs in fancy dress, or as the constitutionalizing of the conventional wisdom. But that is to miss much of the significance of Sunstein's article. In my view, it is of the utmost importance to ground interpretation explicitly in constitutional values. More than that, Sunstein's thesis contributes to a growing literature that attempts to marry the concerns of normative constitutionalism with those of positive political theory. Sunstein at base is asking us to consider this question: If we aspire to be a republican polity of a certain sort, how should we structure our electoral and legislative processes? While Madison might not recognize the republicanism that Sunstein espouses as his own, he certainly would recognize the issue Sunstein frames as one of the most important and troubling that we face as we embark on our second hundred years of republican constitutionalism.

I do not want to conclude, however, on this congratulatory note. The question I have put in Sunstein's mouth is urgent as well as important. More pointedly, I believe that the current form of the debate about American public institutions requires that the question be rephrased if it is to identify properly the controversy that divides centrist reformers like Sunstein (and me) from more radical critics of the Right or Left. For the radicals' challenge is really a challenge to the centrist vision of what it is possible for public life to be like in a liberal democracy. If the Left is correct, then public discourse and collective action under conditions of capitalist economic organization and liberal democratic governance are oppressive and alienating. The attempted pursuit of republican values in this context can only be an illusion. In our secular society, neo-Marxist analysis might simply substitute republicanism for religion as the opiate of the masses.

The public-choice-inspired radical Right agrees, but out of quite different premises. Whereas the Left sees individual preferences as endogenous to an oppressive regime and thus illusory and false as expressed through standard democratic processes, the Right sees preferences as exogenous to politics. More importantly for these latter theorists, the cycling problems of majority rule and other collective choice processes (as well as the ubiquity of interest group hegemony in balkanized political sub-systems) make the construction of legitimate and defensible collective decision mechanisms a virtual impossibility in the modern state. On either view, the relationship between private interests and public decisions has, and can have, nothing to do with the alchemy of disinterested, republican consensus. To think otherwise is to misunderstand both individual and collective behavior at the most fundamental level.

The argument, then, is an argument about what the world of politics is 
or can be like. For if we misunderstand that, we misunderstand what values it is sensible to hold or, more accurately, to seek to implement. Indeed, the republican reformer demanding that statutes be interpreted as if they were the product of republican institutions risks simply extending the reach of private seizures of public power. The republican reformer must, therefore, join issue on the facts-on the positive theory of social or public choice.

Indeed, Sunstein himself has addressed this topic to a degree. ${ }^{28}$ But it is not enough to claim that values are endogenous to politics. Leftist critics will agree but will point out that that is precisely their complaint. Right wing critics, on the other hand, will be heard to wonder what possible difference that could make as long as preferences are not uniform or "single-peaked." Moreover, endogeneity does not of itself equalize power or cause effective political groups to form around even those values that are widely shared. Thus, while one can only welcome the continued devotion of Cass Sunstein's enormous energy and talent to the struggle to define a plausible and attractive view of American politics and public law, one must simultaneously note that the agenda for debate is longer than $\mathrm{Be}$ yond the Republican Revival seems to imagine. Indeed, the conversation is hardly begun.

28. Sunstein, Legal Interference with Private Preferences, 53 U. CHI. L. REv. 1129 (1986); see also Sunstein, Naked Preferences and The Constitution, 84 Colum. L. REv. 1689 (1984); Sunstein, Interest Groups in American Public Law, 38 Stan. L. Rev. 29 (1985). 
